\title{
Economic assessment of electric energy storage for load shifting in positive energy building
}

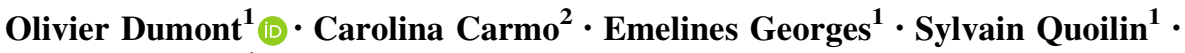 \\ Vincent Lemort ${ }^{1}$
}

Received: 5 October 2016/Accepted: 9 December 2016/Published online: 21 December 2016

(C) The Author(s) 2016. This article is published with open access at Springerlink.com

\begin{abstract}
Net zero energy buildings and positive energy buildings are gaining more and more interest. This paper evaluates the impact of the integration of a battery in a positive energy building used to increase its self-consumption of electricity. Parametric studies are carried out by varying the building envelope characteristics, the power supply system, the climate, the lighting and appliances profiles, the roof tilt angle, the battery size and the electricity tariffs, leading to 3200 cases. The analysis is performed on an annual basis in terms of self-consumption and self-production rate and payback period. It is shown that the battery size leading to the minimum payback period within the input range is comprised between 2.6 and $4.5 \mathrm{kWh}$. The lowest payback periods, ( $\sim 7$ years), are reached with a well-insulated building envelope, a high lightning and appliance consumption, a low feed-in tariff and a $3.7 \mathrm{kWh}$ battery. Finally, simple correlations (based on the feed-in tariff, the annual electrical consumption and production) to predict the optimal size of battery and the lowest payback period are proposed.
\end{abstract}

Olivier Dumont

olivier.dumont@ulg.ac.be

Carolina Carmo

cca@et.aau.dk

Emelines Georges

emeline.georges@ulg.ac.be

Sylvain Quoilin

squoilin@ulg.ac.be

Vincent Lemort

Vincent.Lemort@ulg.ac.be

1 Thermodynamics Laboratory, University of Liege, Liège, Belgium

2 Department of Energy Technology, Aalborg University, Ålborg, Denmark
Keywords Load shifting · Energy storage · Positive energy building $\cdot$ Economic analysis

\begin{tabular}{ll}
\multicolumn{2}{l}{ List of symbols } \\
DD & Discharge depth \\
HP & Heat pump \\
LA & Lighting and appliances \\
$n$ & Number of cycles \\
ORC & Organic Rankine cycle \\
$p$ & Tariff $(€)$ \\
PEB & Positive energy building \\
PV & Photovoltaics \\
$Q$ & Heat $(\mathrm{kWh})$ \\
$R$ & Revenue $(€)$ \\
$r$ & Interest rate \\
$t$ & Time $($ year) \\
$\dot{W}$ & Power $(\mathrm{W})$ \\
$W$ & Energy $(\mathrm{kWh})$
\end{tabular}

\section{Greek symbols}

$\gamma$ Self-consumption (production) factor

\begin{tabular}{ll}
\multicolumn{2}{l}{ Subscripts and supe } \\
bat & Battery \\
bb & Buy-back \\
cons & Consumption \\
D & Demand \\
Opt & Optimal \\
prod & Production \\
r & Retail \\
S & Production \\
us & Usable
\end{tabular}

Subscripts and superscripts

bat Battery

bb Buy-back

cons Consumption

D Demand

Opt Optimal

prod Production

r Retail

us Usable 


\section{Introduction}

The building sector is consuming more than one-third of the world's energy [1]. Net zero energy buildings (NZEB) and positive energy buildings (PEB) are, therefore, gaining a rising interest. The introduction of energy storage in positive energy buildings is increasingly investigated, with the objective of decreasing the dependency on the grid. In this context, electric batteries could play an important role. With decreasing feed-in tariffs, it becomes interesting to consume the electricity generated on-site [2]. Batteries can help to increase self-consumption and also to avoid disconnecting the power system during peak power production. It also decreases the need for backup generation and the need for energy transport.

Residential battery energy storage systems to increase the self-consumption of rooftop solar installations remain economically unfavorable in most of the markets [3]. The recent development of new home battery systems, combined with significant price reductions, has created high expectations in the solar production for the building sector. The technical specifications are similar to previous lithiumion battery systems, but the announced system cost is significantly below market prices at that time.

The economic viability of PV combined with battery storage was evaluated in 2014 in the German context [3]. The authors concluded that, for an economically rational household, investments in battery storage are already profitable for small residential PV systems. The cost assumption for the battery system was, however, notably low $(171+172$ EUR/kW). Other studies, such as [4], find that PV is profitable in the current German regulation scheme, but that batteries require further cost reductions to reach economic viability. In 2016, [5] the economic benefit of the Powerwall (Tesla battery) for end-users with respect to various influencing parameters was assessed. The Powerwall ( $\sim 417 € / \mathrm{kWh}$ ) [5] could be a profitable investment in some, but not all scenarios investigated. Also, [6] showed that although decreasing at a fast pace, the cost of domestic Li-ion storage is most likely still too high for a large-scale market uptake in Europe.

The aim of this paper is to study the influence on the performance and on economic considerations of a battery coupled with a solar production system with a wide range of configuration. The first section is a short introduction to present the context of the paper. The next section describes the modelling methods and the different inputs in terms of building envelope, power supply system, climate, lightning and appliances profiles, roof tilt angle, battery size and electricity tariffs. The results of annual simulations of 3200 different case studies are presented and analysed in subsequent section. The trends of self-consumption, number of cycles and payback period are depicted in function of the battery size. The optimal battery and the lowest payback period are given for each case study. Finally, simple correlations (based on the feed-in tariff, the annual electrical consumption and production) to predict the optimal size of battery and the lowest payback period are proposed.

\section{Modelling}

The modelling of the system is performed with the Dymola software and the Coolprop and Thermocycle libraries [7]. The global model and sub-components are extensively presented in [8]. The model comprises a 5 zones building $\left(135 \mathrm{~m}^{2}\right)$, a $140 \mathrm{~m}^{2}$ roof, a multi-node model of $500 \mathrm{~L}$ water storage, a heat pump (4 kWe) and a $5.3 \mathrm{kWe}$ power production system (PV or ORC). These components and configuration will remain unchanged for all the simulations in this paper. A control block selects the mode to be operated at each time step. The control strategy ensures that the heat demand is covered while producing electricity with the ORC system with the surplus heat. The inputs are the weather and the occupant's behaviour. Several simulation parameters are varied: the building envelope, the power supply system, the climate, the lightning and appliance profile, the roof tilt and, the battery size and the electricity tariff. The selected solver (DASSL) uses an adaptive time step, but is not allowed to exceed $900 \mathrm{~s}$ for these yearly simulations. Demand response strategies with smart management of the electrical loads can substantially increase the self-consumption factor (up to $40 \%$ for small battery capacities) [9]. However, it has been shown that for high penetration levels, which is the case for positive energy building, batteries are the most effective option while demand side management performs better at low overproduction levels [10]. In this paper, demand side management is not considered because an optimized control scheme is required, which would lead to excessive CPU time. Furthermore, such modulation strategies require smart-meters and smart-loads which are still at an early stage of practical implementation.

\section{Power system}

Two systems are investigated in this paper: a heat pump combined with PV panels and a more innovative technology including a reversible HP/ORC unit [11] (Fig. 1). A HP/ORC reversible unit is a heat pump which is slightly modified [11] to also operate as an organic Rankine cycle (ORC). This reversible unit coupled to a passive house, a large solar thermal roof and a horizontal ground heat exchanger constitutes a polyvalent system able to provide both electricity and heat to the household [12]. These two 
Fig. 1 Layout of the heat pump combined with PV panels (left) and of the reversible HP/ORC system

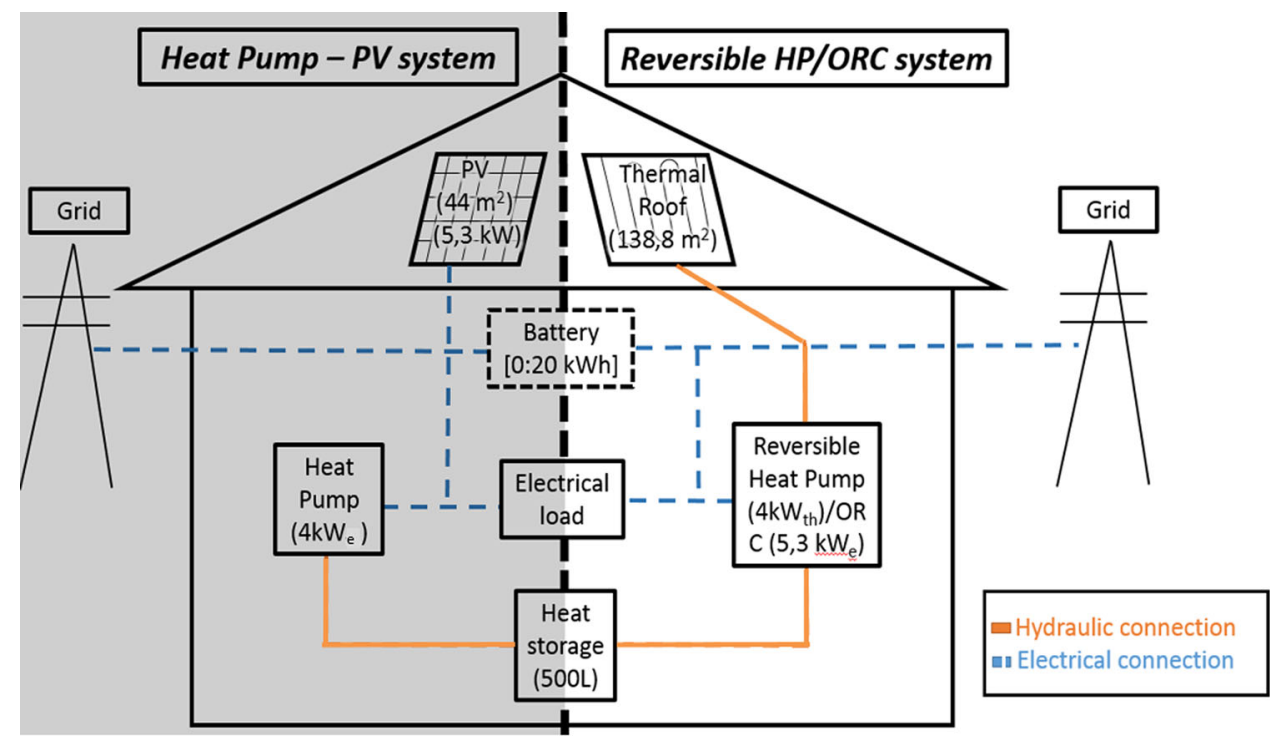

systems are investigated because they present very different generation patterns. The reversible HP/ORC unit produces electricity mainly around midday when the electrical load of the residential building is low, while the PV system presents a better match between generation and consumption.

The reversible HP/ORC system has an annual electrical production $20-50 \%$ lower than that of the PV. However, it benefits from direct heating from the solar roof, which also influences the global performance [13]. The nominal powers $(5.3 \mathrm{~kW})$ of both systems are equal in summer nominal conditions (outdoor temperature equals $25{ }^{\circ} \mathrm{C}$ and global radiation equals $800 \mathrm{~W} / \mathrm{m}^{2}$ ). The area of PV panels is $44 \mathrm{~m}^{2}$ while the solar panel covers the whole roof $\left(138.8 \mathrm{~m}^{2}\right)$.

\section{Battery and inverter}

The battery model is based on the characteristics of domestic battery with the lowest specific selling price nowadays [14]. The roundtrip mean watt-hour efficiency is $92 \%$, the cost should be around $450 € / \mathrm{kWh}$ for a battery in 2020 [15]. It should be noted that this hypothesis is optimistic but it can, however, be seen as a reasonable investment cost in a few years from now [15]. The maximum power (charge or discharge) is limited to $3300 \mathrm{~W}$. The installation cost plus the inverter cost are assumed equal to $890 €$ for all battery sizes [15]. The efficiency of the inverter is $97 \% .90 \%$ of the usable battery capacity is used during the lifetime on average. The battery float charge losses (energy to maintain the battery charged when it is full), is assumed to be zero. When the total electrical load of the building is lower than the PV production, the battery is charging within its power limitation. When the load is higher than the PV production and the battery is not empty, the battery discharges to avoid buying electricity on the grid. Considering the lifetime, the battery is guaranteed for 10 years (or 3650 cycles). An optimum battery size exists for each simulation case: a too large battery leads to high investments and poor utilization rates while a too small battery leads to in sufficient load shifting capability.

\section{Building envelope}

Two different building envelope characteristics-K20 and K30 [16] are studied. They differ in terms of coefficient of heat transmission and air tightness (Table 1). The K30 building leads to higher heat pump consumption (roughly twice more). This can also strongly influence the selfconsumption factor because this thermal need occurs mainly in winter when the power production is low.

\section{Lighting and appliances}

As modelled by Georges et al. [17], two lighting and appliances profiles (LA) are simulated. The latter differ in the magnitude of power demand. LA 3000 is characterized by the highest demand (3000 kWh/year) and LA1491 presents a $1491 \mathrm{kWh} /$ year consumption. These electrical consumptions comprise all non-HVAC electrical loads.

Table 1 Envelope characteristics of different typical buildings

\begin{tabular}{lll}
\hline Coefficients of heat transmission and infiltration rate & $\mathrm{K} 20$ & $\mathrm{~K} 30$ \\
\hline Roof $\left(\mathrm{W} / \mathrm{m}^{2} \mathrm{~K}\right)$ & 0.09 & 0.228 \\
Floor slab $\left(\mathrm{W} / \mathrm{m}^{2} \mathrm{~K}\right)$ & 0.08 & 0.258 \\
External wall $\left(\mathrm{W} / \mathrm{m}^{2} \mathrm{~K}\right)$ & 0.15 & 0.245 \\
Window $\left(\mathrm{W} / \mathrm{m}^{2} \mathrm{~K}\right)$ & 0.63 & 1.2 \\
Infiltration rate $(50 \mathrm{~Pa})\left(\mathrm{m}^{3} / \mathrm{h} \mathrm{m}^{2}\right)$ & 0.35 & 2.51 \\
\hline
\end{tabular}




\section{Climate}

Knight et al. [18] has shown that European climate can roughly be divided into five different typical zones. The system is, therefore, simulated for five cities located in each zone (from north to south): Copenhagen, Frankfurt, Torino, Roma and Palermo. The weather data (typical meteorological years) used for the outdoor temperature and the solar irradiance are provided by the EnergyPlus Energy Simulation Software [19]. The weather data consists in outdoor temperature, global and diffuse radiation. The radiations on each wall and roof are computed with respect to their orientations and tilts at each time step. The climate impacts both the thermal needs of the building and the electrical production of the power system.

\section{Electricity tariff}

Due to the large number of parameters, only two different electricity prices are investigated. The first electricity price investigated uses the retail and buy-back tariffs provided by real data from Denmark [20]. It leads to an average retail tariff of $0.28 € / \mathrm{kWh}$ and a feed-in tariff of $0.17 € / \mathrm{kWh}$. The second tariff is an extreme case where no electricity is sold on the grid (only a retail tariff of $0.28 € / \mathrm{kWh}$. Because the feedin-tariffs are expected to decrease in the next years, the real solution should fit in between these two options.

\section{Roof orientation}

In this study, only south-oriented roofs are considered to limit the number of study cases which is already high. Two different tilt angles are considered $\left(5^{\circ}\right.$ and $\left.35^{\circ}\right)$. The orientation of the solar generator impacts the temporal electricity production. A horizontal solar roof orientation leads to higher summer production and lower winter production and therefore to lower self-consumption of the system.

\section{Summary}

Table 2 summarizes the input parameters and their investigated values. Each annual simulation requires $3 \mathrm{~h}$ CPU time. The number of parameters to be tested is, therefore, limited. In this study, 160 annual simulations combining 20 battery sizes (leading to 3200 different cases) are analysed ("Appendix"-Table 4). These parameters cannot capture the whole range of PEB parameters in Europe but encompass the largest number of domestic cases by testing two extreme values of each parameter with a Monte-Carlo analysis (Table 2).

\section{Results}

\section{Performance criteria}

Several indices allow to determine the performance of a given system. The annual cash-flow, $R$, is defined in (1), where $\dot{W}_{\text {net }}$ is the net electrical power, including HP and LA consumption, battery power and power production from the power system), $p_{\mathrm{r}}(€ / \mathrm{kWh})$ is the retail price considered when the net electrical power is negative and $p_{\text {bb }}$ is the buy-back tariff ( $\left.€ / \mathrm{kWh}\right)$ considered when the net electrical power generation is positive.

$R=\sum_{0}^{t}\left(p_{\text {bb }} \max \left(\dot{W}_{\text {net }}, 0\right)+p_{\mathrm{r}} \min \left(\dot{W}_{\text {net }}, 0\right)\right) \cdot \Delta t$

For the sake of simplicity, Eq. (1) neglects more complex tariff structures such as fixed grid costs or taxes and

Table 2 Input parameters

\begin{tabular}{lll}
\hline Parameter & Name & Value \\
\hline Lighting and appliances & LA1491 & $1491 \mathrm{kWh} /$ year \\
Building & LA3000 & $3000 \mathrm{kWh} /$ year \\
& K20 & Global heat transfer coefficient $=0.2 \mathrm{~W} /\left(\mathrm{m}^{2} \mathrm{~K}\right)$ \\
Power system & K30 & Global heat transfer coefficient $=0.3 \mathrm{~W} /\left(\mathrm{m}^{2} \mathrm{~K}\right)$ \\
& PV & $44 \mathrm{~m}^{2}(5.3 \mathrm{~kW})$ \\
Roof tilt angle & ORC & $5.3 \mathrm{~kW}$ \\
& R5 & $5^{\circ}$ \\
Battery & R35 & $35^{\circ}$ \\
Climate & B1-B20 & $(1: 20) \mathrm{kWh}$ \\
Electricity price & Copenhagen, Frankfurt, & \\
& Torino, Roma, Palermo $)$ & Buy: $0.28 € / \mathrm{kWh}$ and feed-in: $0.17 € / \mathrm{kWh}$ \\
\hline
\end{tabular}


incentives on self-consumption, because there regulations are being implemented in very different ways in different countries [2].

The self-consumption rate [21] or demand cover factor $\left(\gamma_{D}\right)$, represents the fraction of energy consumption which has been produced by the building from the grid point of view, taking the battery power into account $(2) . W_{\text {cons+ }}$ is the net electrical consumption of the building including heat pump, lights and appliances and battery charging and discharging.

$\gamma_{\mathrm{D}}=\frac{\sum \min \left(\mathrm{W}_{\text {cons+. }}, \mathrm{W}_{\text {prod }}\right)}{\sum W_{\text {cons }+.}}$

The self-production rate [21] or production cover factor $\left(\gamma_{\mathrm{S}}\right)$, represents the fraction of energy production which has been consumed (3).

$\gamma_{\mathrm{S}}=\frac{\sum \min \left(\mathrm{W}_{\text {cons }+.}, \mathrm{W}_{\text {prod }}\right)}{\sum W_{\text {prod. }}}$

The payback period, PB, for a battery is determined by equalling the battery investment, $P_{\text {battery }}$ to the revenues related to the battery (4). $r$ is the discount rate (0.04). The payback period is preferred to the net present value (on a 10 years basis) because this last one is negative for the majority of the cases. Furthermore, it is better to keep time as a parameter instead of fixing it to a given duration because the life cycle of the battery depends of the study case (number of cycles) and could evolve in the next decade.

$P_{\text {battery }}=\frac{\sum_{i=0}^{\mathrm{PB}}\left(R_{\text {bat }}-R_{\text {no_bat }}\right)}{(1+r)^{i}}$

The discharge depth is defined as the annual stored energy divided by 365 times the usable battery capacity (5). The average usable battery capacity is taken equal to $90 \%$ of the total battery capacity.

$\mathrm{DD}=\frac{W_{\text {bat, }, \text { stored }}}{365 \cdot W_{\text {bat,us }}}$

The number of equivalent storage cycles, $n$, is estimated by the ratio of the annual charged energy and the usable capacity of the battery (6). It is equal to the discharge depth times 365 .

$n=\frac{W_{\text {bat }, \text { stored }}}{W_{\text {bat,us }}}$

\section{Parametric study}

A wide range of conditions has been tested with a total of 3200 different cases (combination of two roof tilt angles, two electricity tariffs, two building envelope, two LA profiles, two power production systems, 5 climates and 20 different battery sizes). The range of outputs given by the model is exposed in Table 3.

Presenting the results of the 3200 study cases is of course not possible. Table 4 ("Appendix") shows the results for 160 simulations with optimized battery size leading to the lowest payback period. A few examples of typical results are shown in this section. Figure 2 presents the evolution of the electric self-consumption and production, discharge depth and payback time versus the battery size. The case study is in Copenhagen with $1491 \mathrm{kWh} /$ year of lighting and appliances consumption, K20 building, a roof tilt of $35^{\circ}$ and a PV system.

The average daily discharge depth starts with high values for small batteries (higher than one in some cases) and decreases asymptotically when increasing the battery size. A compromise between the lifetime of the battery and an optimal battery use (high discharge depth) must, therefore be found. The optimum payback period results in a compromise between investment (better for small batteries) and annual revenues (better for large batteries). The payback period is decreasing sharply when increasing the size for small battery capacities. After the minimum of payback time is reached, the curve is increasing slowly with the battery size. It is, therefore, more interesting to have an over-sized battery than an undersized battery. The selfconsumption and production factor are analysed more in details here under (Fig. 3).

The self-production rate is rather low (always below $50 \%$ ) mainly because the electrical production is much

Table 3 Outputs range

\begin{tabular}{lll}
\hline Outputs & Nomenclature & Range \\
\hline Annual electrical production $(\mathrm{kWh})$ & $E_{\text {prod }}$ & $(3351: 11812)$ \\
Annual heat pump consumption $(\mathrm{kWh})$ & $E_{\mathrm{HP}, \text { cons }}$ & $(0: 2492)$ \\
Annual electrical consumption $(\mathrm{kWh})$ & $E_{\text {cons }}$ & $(1491: 5491)$ \\
Annual heat consumption $(\mathrm{kWh})$ & $Q_{\mathrm{HP}, \mathrm{cons}}$ & $(837: 8679)$ \\
Payback period (years) & $\mathrm{PB}$ & $(7.24: 26.5)$ \\
Self-production rate $(\%)$ & $\gamma_{\mathrm{S}}$ & $(8.3: 81.2)$ \\
Self-consumption rate $(\%)$ & $\gamma_{\mathrm{D}}$ & $(5.8: 46.1)$ \\
Annual number of cycles $(-)$ & $N$ & $(32: 409)$ \\
\hline
\end{tabular}




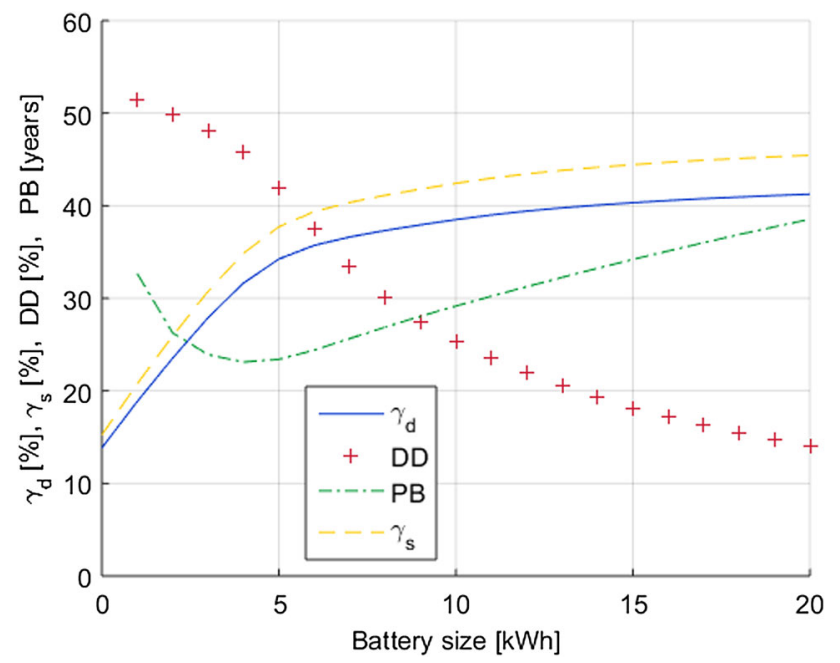

Fig. 2 Evolution of the electric self-consumption and production, discharge depth and payback time versus the battery size. Case study is in Copenhagen with $1491 \mathrm{kWh} /$ year of lighting and appliances consumption, K20 building, a roof tilt of $35^{\circ}$ and a PV system

larger than the electrical consumption (see section "Optimal battery size and payback period"). The self-consumption rate varies in a wide range (9-80\%) depending on the studied case. When increasing the battery size, the increase in self-consumption rate is relatively sharp for low battery size (up to $5 \mathrm{kWh}$ ). But, when the daily average electrical consumption of the building is fully covered by the power system combined with the battery, the increase in self-production rate is moderate. It can also be noted that the largest battery $(20 \mathrm{kWh})$ cannot lead to a full independency of the building from the electricity grid. Batteries are well adapted to daily variations but not to longer periods of time (seasonal shift) as already shown in [22]. This conclusion applies for building electrical load representing from 12 to $97 \%$ of the annual electrical production. Globally, the self-production and self-consumption rates decrease with a poorly insulated building because the

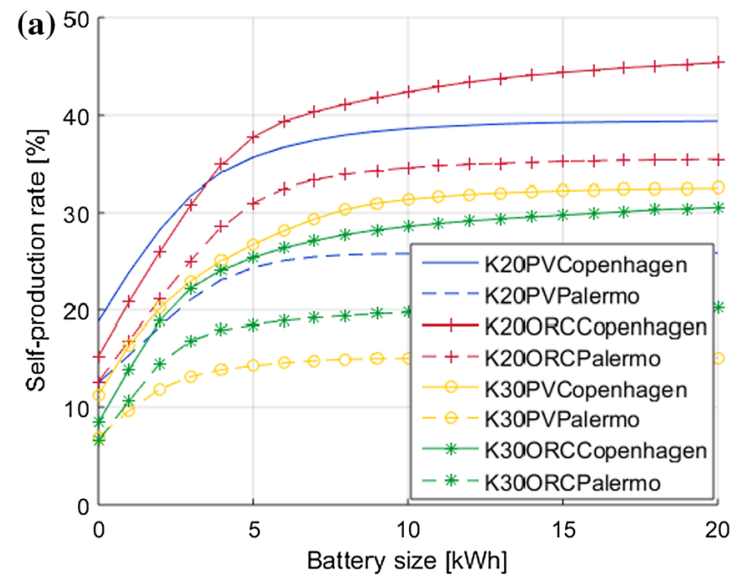

higher electrical production of the heat pump in winter is not covered by the solar electrical production. The PV system presents a lower self-production rate because it generates higher power than the ORC system around midday when the electrical consumption is already covered by the solar electrical production. On the contrary, the PV system outperforms the ORC system in terms of self-consumption rate. ORC systems (or more generally, systems presenting a low self-consumption) benefits of a higher increase in the self-consumption and self-production through the use of a battery compared to PV systems. Lower latitudes (Palermo) shows higher self-production and self-consumption rates. The average self-production and consumption rates without battery increases function of the lighting and appliance consumption (Fig. 4). The influence of the roof tilt angle is not presented here because it is almost negligible (see "Appendix"-Table 4).

\section{Optimal battery size and payback period}

In the former section, it has been observed that each case study presents an optimal battery size corresponding to the lowest payback period. Despite the large size of battery simulated (up to $20 \mathrm{kWh}$ ) and the large size of commercial products (up to $10 \mathrm{kWh}$ ), the optimal battery size for the 160 study cases only varies between 2.6 and $4.5 \mathrm{kWh}$ (Fig. 3a). A Gaussian Process sensitivity analysis [18] is performed to select the most relevant inputs to predict the optimal battery size with GPExp. The mean average relative error [23] (MARE) is used to select the optimal number of inputs (the lowest the MARE, the better the quality of prediction). From Fig. 7a ("Appendix"), it can be seen that the electrical production and consumption are the two most relevant inputs to predict the optimal battery size. The relevance of the other simulation parameters is almost negligible (it is not the case, however for the

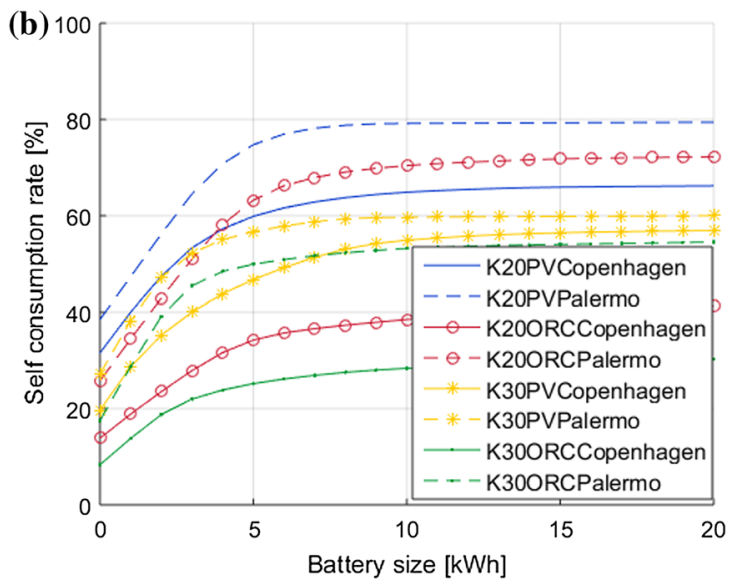

Fig. 3 a Self-production rate. b Self-consumption rate. In the legend, K30 (i.e. K20) corresponds to the building envelope presenting the higher (i.e. lower) losses. PV or orc refers to the production system while the location is added at the end 
prediction of $\mathrm{PB}$ ): using more inputs would lead to a more complicated regression and to a possible over-fitting of the data. As a consequence, a correlation to predict the optimal battery size is proposed as a function of these two parameters (7).

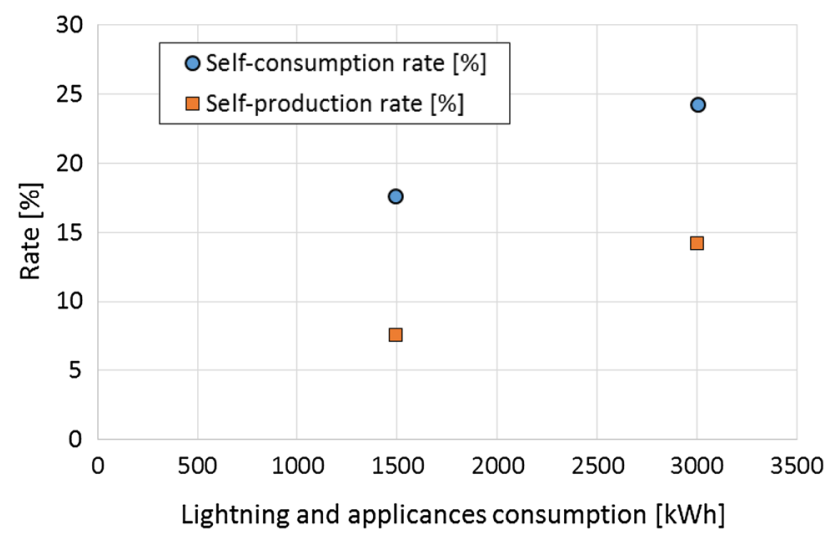

Fig. 4 Average self-production and consumption rates in function of the lighting and appliance consumption

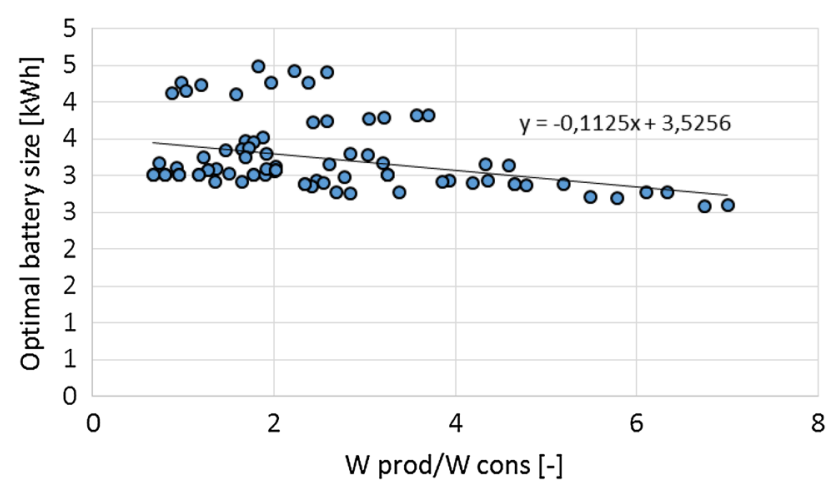

Fig. 5 Optimal battery size in function of the ratio between annual electricity production and consumption

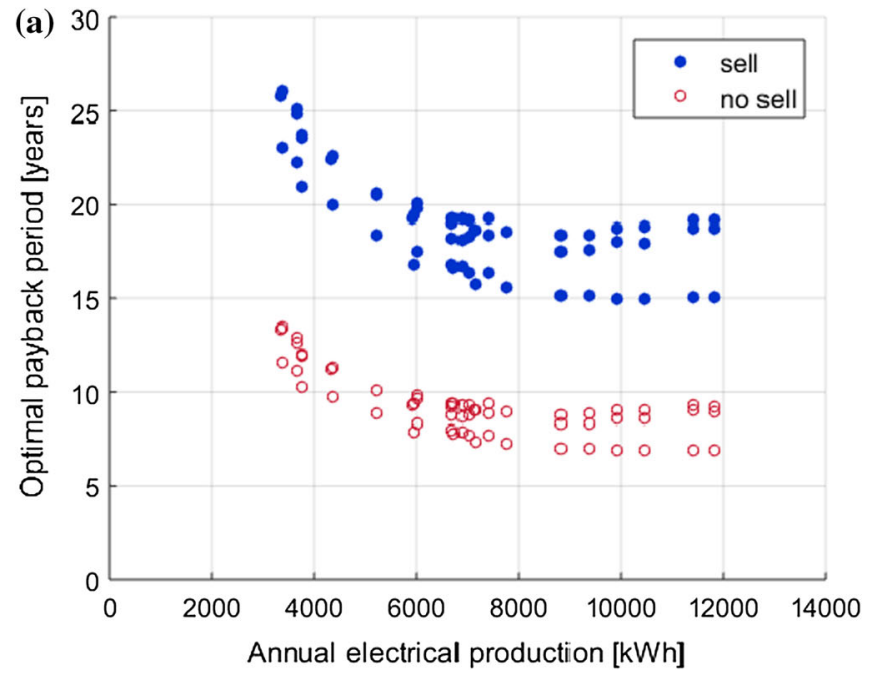

$E_{\text {bat }, \text { opt }}=3.52-0.1125 \frac{W_{\text {prod }}}{W_{\text {cons }}}$

It only considers the ratio between annual electricity production and consumption. The correlation could seem hardly acceptable because of the large maximum error of $1.2 \mathrm{kWh}$ but (Fig. 5):

- Only a small number of points deviate largely from the trend. The mean average error is $0.35 \mathrm{kWh}$ which is deemed acceptable.

- This correlation encompass a very large number of cases (3200) with very different inputs. This correlation is valid for the buildings, lighting and appliance ranges, locations, roof tilt angles and electricity prices listed in Table 2.

- One of the perspective of this work is to enlarge the parametric study with even more cases.

Also, the optimal payback period (i.e. the lowest payback period simulated with the 20 battery sizes) is plotted in Fig. 6a versus the annual electrical production. The lowest payback periods, ( $\sim 7$ years $)$, are reached with a well-insulated building envelope (K20), a high lighting and appliance consumption (LA3000), a low feed-in tariff (no_sell) and a $3.5 \mathrm{kWh}$ battery. The payback period is very high (not actually economically feasible) in the case of the feed-in tariff of $0.17 € / \mathrm{kWh}$ (blue points - sell). On the contrary, the red points (no sell-no feed-in tariff) shows low payback period which indicates that batteries could be economically viable at the considered (optimistic) investment cost. An optimum is observed: For low annual electrical production, the optimum payback period decreases sharply while for high annual electrical load, the optimal payback period slightly increases. A correlation (8) is therefore proposed to take into account the two main relevant inputs (also selected

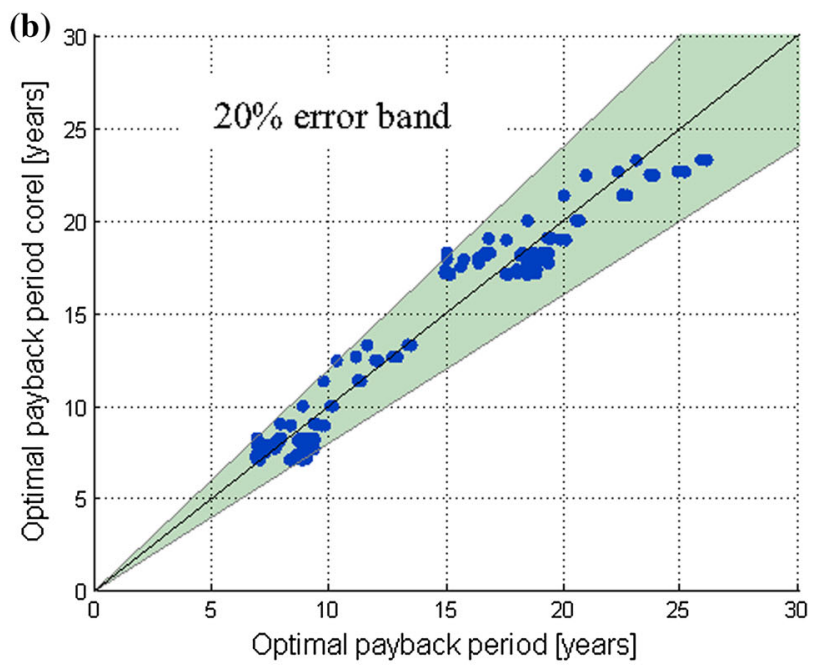

Fig. 6 a Optimal payback period in function of annual electrical production. b Comparison of the optimal payback period versus the one predicted by the correlation ( $20 \%$ error bands) 
with a Gaussian regression-Fig. 7b-“Appendix"): the electricity feed-in tariff, $p_{\mathrm{bb}}$, and the annual electrical production, $W_{\text {prod. }}$. The same remark on the acceptability of the Eq. (7) applies for Eq. (8).

$$
\begin{aligned}
\mathrm{PB}_{\mathrm{opt}}= & 23.55-58.6 .\left(p_{\mathrm{r}}-p_{\mathrm{bb}}\right)+1.768 \\
& \times 10^{-7}\left(W_{\text {prod }}-9260\right)^{2}
\end{aligned}
$$

Fig. 6 shows that the correlations predicts the optimal payback period with a decent accuracy only with two inputs.

\section{Conclusion}

This paper investigates the integration of batteries in positive energy buildings. Annual simulations are performed to analyse the performance and the economic aspects. Contrary to the recent literature in the topic $[5,6]$, detailed non-linear models of each component have been used. Although results depend on the assumptions (electricity tariffs, investment costs, battery performance, no demand side management...), a varied set of parametric studies has been carried out to assess the performance of the system investigated in a wide range of conditions. It has been shown that the battery size leading to the minimum payback period is comprised between 2.6 and $4.5 \mathrm{kWh}$. These values are lower than the current cheapest batteries available on the market [14]. However, an over-sized battery will lead to a lower number of cycles leading to a higher life expectancy and a higher self-consumption. Finally, a simple empirical correlation to predict the optimal size of battery and the lowest payback period are proposed based on the annual electrical production and consumption and the feed-in tariff. More simulations should be performed to assess the validity of the correlations in a wide range of inputs (higher roof tilt angle, other building envelopes, more lighting and appliances profiles...). The economic interest has not been reached yet because of the high payback periods. The battery price still needs to decrease while regulatory framework should change to promote the self-consumption in buildings.

Open Access This article is distributed under the terms of the Creative Commons Attribution 4.0 International License (http://creative commons.org/licenses/by/4.0/), which permits unrestricted use, distribution, and reproduction in any medium, provided you give appropriate credit to the original author(s) and the source, provide a link to the Creative Commons license, and indicate if changes were made.

\section{Appendix}

See Table 4 and Fig. 7.

\begin{tabular}{|c|c|c|c|c|c|c|c|c|c|c|c|c|}
\hline Building & LA & System & $\begin{array}{l}\text { Tilt } \\
\left({ }^{\circ} \mathrm{C}\right)\end{array}$ & $\begin{array}{l}\text { Lattitude } \\
\left({ }^{\circ}\right)\end{array}$ & $\begin{array}{l}\mathrm{Q}_{\text {cons }} \\
(\mathrm{kWh})\end{array}$ & $\begin{array}{l}\mathrm{Q}_{\text {prod }} \\
(\mathrm{kWh})\end{array}$ & $\begin{array}{l}\text { Optim bat } \\
(\mathrm{kWh})\end{array}$ & $\begin{array}{l}\text { Optim bat no } \\
\text { sell (kWh) }\end{array}$ & $\begin{array}{l}\text { PB optim } \\
\text { (years) }\end{array}$ & $\begin{array}{l}\text { PB optim no } \\
\text { sell (years) }\end{array}$ & $\begin{array}{l}\gamma_{\mathrm{d}} \\
(\%)\end{array}$ & $\begin{array}{l}\gamma_{\mathrm{s}} \\
(\%)\end{array}$ \\
\hline K20 & LA3000 & PV & R35 & 56 & 4081 & 6874 & 3 & 3 & 17 & 8 & 31 & 18 \\
\hline K20 & LA3000 & PV & R35 & 51 & 3948 & 7404 & 4 & 4 & 16 & 8 & 32 & 17 \\
\hline K20 & LA3000 & PV & R35 & 45 & 3618 & 9371 & 4 & 4 & 15 & 7 & 34 & 14 \\
\hline K20 & LA3000 & PV & R35 & 42 & 3257 & 10466 & 4 & 4 & 15 & 7 & 39 & 13 \\
\hline K20 & LA3000 & PV & R35 & 38 & 3190 & 11813 & 4 & 4 & 15 & 7 & 38 & 12 \\
\hline K20 & LA3000 & PV & R5 & 56 & 4084 & 6701 & 3 & 3 & 17 & 8 & 32 & 19 \\
\hline K20 & LA3000 & PV & R5 & 51 & 3951 & 7024 & 3 & 3 & 16 & 8 & 32 & 18 \\
\hline K20 & LA3000 & PV & R5 & 45 & 3621 & 8818 & 4 & 4 & 15 & 7 & 34 & 15 \\
\hline K20 & LA3000 & PV & R5 & 42 & 3258 & 9921 & 4 & 4 & 15 & 7 & 38 & 14 \\
\hline K20 & LA3000 & PV & R5 & 38 & 3191 & 11396 & 4 & 4 & 15 & 7 & 38 & 13 \\
\hline K20 & LA3000 & ORC & R35 & 56 & 3767 & 3667 & 4 & 4 & 22 & 11 & 14 & 14 \\
\hline K20 & LA3000 & ORC & R35 & 51 & 3640 & 4357 & 4 & 4 & 20 & 10 & 16 & 13 \\
\hline K20 & LA3000 & ORC & R35 & 45 & 3288 & 6022 & 4 & 4 & 18 & 8 & 20 & 12 \\
\hline K20 & LA3000 & ORC & R35 & 42 & 3029 & 6727 & 4 & 4 & 17 & 8 & 24 & 12 \\
\hline K20 & LA3000 & ORC & R35 & 38 & 3000 & 7758 & 4 & 4 & 16 & 7 & 26 & 12 \\
\hline K20 & LA3000 & ORC & R5 & 56 & 3819 & 3363 & 4 & 4 & 23 & 12 & 14 & 15 \\
\hline K20 & LA3000 & ORC & R5 & 51 & 3659 & 3767 & 4 & 4 & 21 & 10 & 15 & 14 \\
\hline K20 & LA3000 & ORC & R5 & 45 & 3285 & 5214 & 4 & 4 & 18 & 9 & 19 & 13 \\
\hline K20 & LA3000 & ORC & R5 & 42 & 3029 & 5953 & 4 & 4 & 17 & 8 & 23 & 14 \\
\hline K20 & LA3000 & ORC & R5 & 38 & 3000 & 7131 & 4 & 4 & 16 & 7 & 26 & 13 \\
\hline K20 & LA1491 & PV & R35 & 56 & 2778 & 6874 & 3 & 3 & 19 & 9 & 27 & 11 \\
\hline
\end{tabular}

Table 4 Summary of results 
Table 4 continued

\begin{tabular}{|c|c|c|c|c|c|c|c|c|c|c|c|c|}
\hline Building & LA & System & $\begin{array}{l}\text { Tilt } \\
\left({ }^{\circ} \mathrm{C}\right)\end{array}$ & $\begin{array}{l}\text { Lattitude } \\
\left({ }^{\circ}\right)\end{array}$ & $\begin{array}{l}\mathrm{Q}_{\text {cons }} \\
(\mathrm{kWh})\end{array}$ & $\begin{array}{l}\text { Qprod } \\
(\mathrm{kWh})\end{array}$ & $\begin{array}{l}\text { Optim bat } \\
(\mathrm{kWh})\end{array}$ & $\begin{array}{l}\text { Optim bat no } \\
\text { sell }(\mathrm{kWh})\end{array}$ & $\begin{array}{l}\text { PB optim } \\
\text { (years) }\end{array}$ & $\begin{array}{l}\text { PB optim no } \\
\text { sell (years) }\end{array}$ & $\begin{array}{l}\gamma_{\mathrm{d}} \\
(\%)\end{array}$ & $\begin{array}{l}\gamma_{\mathrm{s}} \\
(\%)\end{array}$ \\
\hline K20 & LA1491 & PV & R35 & 51 & 2609 & 7407 & 3 & 3 & 19 & 9 & 28 & 10 \\
\hline K20 & LA1491 & PV & $\mathrm{R} 35$ & 45 & 2236 & 9371 & 3 & 3 & 18 & 9 & 30 & 8 \\
\hline K20 & LA1491 & PV & R35 & 42 & 1806 & 10465 & 3 & 3 & 19 & 9 & 35 & 7 \\
\hline K20 & LA1491 & PV & $\mathrm{R} 35$ & 38 & 1686 & 11812 & 3 & 3 & 19 & 9 & 36 & 7 \\
\hline K20 & LA1491 & PV & $\mathrm{R} 5$ & 56 & 2780 & 6705 & 3 & 3 & 19 & 9 & 27 & 11 \\
\hline K20 & LA1491 & PV & $\mathrm{R} 5$ & 51 & 2612 & 7024 & 3 & 3 & 19 & 9 & 28 & 11 \\
\hline K20 & LA1491 & PV & $\mathrm{R} 5$ & 45 & 2240 & 8819 & 3 & 3 & 18 & 9 & 30 & 9 \\
\hline K20 & LA1491 & PV & $\mathrm{R} 5$ & 42 & 1808 & 9919 & 3 & 3 & 19 & 9 & 35 & 8 \\
\hline K20 & LA1491 & PV & $\mathrm{R} 5$ & 38 & 1687 & 11398 & 3 & 3 & 19 & 9 & 36 & 7 \\
\hline K20 & LA1491 & ORC & $\mathrm{R} 35$ & 56 & 2434 & 3665 & 3 & 3 & 25 & 13 & 12 & 8 \\
\hline K20 & LA1491 & ORC & $\mathrm{R} 35$ & 51 & 2284 & 4356 & 3 & 3 & 23 & 11 & 14 & 7 \\
\hline K20 & LA1491 & ORC & $\mathrm{R} 35$ & 45 & 1881 & 6018 & 3 & 3 & 20 & 10 & 17 & 6 \\
\hline K20 & LA1491 & ORC & $\mathrm{R} 35$ & 42 & 1544 & 6723 & 3 & 3 & 19 & 9 & 21 & 6 \\
\hline K20 & LA1491 & ORC & $\mathrm{R} 35$ & 38 & 1491 & 7756 & 3 & 3 & 19 & 9 & 24 & 6 \\
\hline K20 & LA1491 & ORC & R5 & 56 & 2479 & 3360 & 3 & 3 & 26 & 13 & 12 & 8 \\
\hline K20 & LA1491 & ORC & $\mathrm{R} 5$ & 51 & 2295 & 3766 & 3 & 3 & 24 & 12 & 13 & 8 \\
\hline K20 & LA1491 & ORC & $\mathrm{R} 5$ & 45 & 1876 & 5210 & 3 & 3 & 21 & 10 & 17 & 7 \\
\hline K20 & LA1491 & ORC & $\mathrm{R} 5$ & 42 & 1541 & 5949 & 3 & 3 & 19 & 9 & 21 & 7 \\
\hline K20 & LA1491 & ORC & $\mathrm{R} 5$ & 38 & 1491 & 7129 & 3 & 3 & 19 & 9 & 24 & 7 \\
\hline K30 & LA3000 & PV & R35 & 56 & 5040 & 3351 & 3 & 3 & 26 & 13 & 8 & 8 \\
\hline K30 & LA3000 & PV & R35 & 51 & 4704 & 3755 & 3 & 3 & 24 & 12 & 10 & 8 \\
\hline K30 & LA3000 & PV & R35 & 45 & 4090 & 5200 & 3 & 3 & 20 & 10 & 12 & 7 \\
\hline K30 & LA3000 & PV & R35 & 42 & 3332 & 5932 & 3 & 3 & 19 & 9 & 15 & 7 \\
\hline K30 & LA3000 & PV & R35 & 38 & 3037 & 7116 & 3 & 3 & 19 & 9 & 17 & 6 \\
\hline K30 & LA3000 & PV & R5 & 56 & 5492 & 6702 & 3 & 3 & 18 & 9 & 20 & 11 \\
\hline K30 & LA3000 & PV & R5 & 51 & 5172 & 7028 & 3 & 3 & 18 & 9 & 21 & 11 \\
\hline K30 & LA3000 & PV & R5 & 45 & 4609 & 8821 & 3 & 3 & 18 & 8 & 21 & 9 \\
\hline K30 & LA3000 & PV & R5 & 42 & 3796 & 9921 & 3 & 3 & 18 & 9 & 26 & 8 \\
\hline K30 & LA3000 & PV & R5 & 38 & 3373 & 11395 & 3 & 3 & 19 & 9 & 27 & 7 \\
\hline K30 & LA3000 & ORC & R35 & 56 & 4996 & 3656 & 3 & 3 & 25 & 13 & 8 & 8 \\
\hline K30 & LA3000 & ORC & R35 & 51 & 4692 & 4344 & 3 & 3 & 22 & 11 & 10 & 7 \\
\hline K30 & LA3000 & ORC & R35 & 45 & 4096 & 6007 & 3 & 3 & 20 & 10 & 12 & 6 \\
\hline K30 & LA3000 & ORC & R35 & 42 & 3336 & 6704 & 3 & 3 & 19 & 9 & 15 & 6 \\
\hline K30 & LA3000 & ORC & R35 & 38 & 3040 & 7743 & 3 & 3 & 19 & 9 & 18 & 6 \\
\hline K30 & LA3000 & ORC & R5 & 56 & 5040 & 3351 & 3 & 3 & 26 & 13 & 8 & 8 \\
\hline K30 & LA3000 & ORC & $\mathrm{R} 5$ & 51 & 4704 & 3755 & 3 & 3 & 24 & 12 & 10 & 8 \\
\hline K30 & LA3000 & ORC & $\mathrm{R} 5$ & 45 & 4090 & 5200 & 3 & 3 & 20 & 10 & 12 & 7 \\
\hline K30 & LA3000 & ORC & $\mathrm{R} 5$ & 42 & 3332 & 5932 & 3 & 3 & 19 & 9 & 15 & 7 \\
\hline $\mathrm{K} 30$ & LA3000 & ORC & $\mathrm{R} 5$ & 38 & 3037 & 7116 & 3 & 3 & 19 & 9 & 17 & 6 \\
\hline K30 & LA1491 & PV & R35 & 56 & 3978 & 6873 & 3 & 3 & 18 & 9 & 20 & 11 \\
\hline K30 & LA1491 & PV & $\mathrm{R} 35$ & 51 & 3655 & 7403 & 3 & 3 & 18 & 9 & 21 & 10 \\
\hline $\mathrm{K} 30$ & LA1491 & PV & $\mathrm{R} 35$ & 45 & 3089 & 9374 & 3 & 3 & 18 & 8 & 21 & 8 \\
\hline K30 & LA1491 & PV & R35 & 42 & 2282 & 10469 & 3 & 3 & 18 & 9 & 26 & 8 \\
\hline K30 & LA1491 & PV & $\mathrm{R} 35$ & 38 & 1861 & 11809 & 3 & 3 & 19 & 9 & 27 & 7 \\
\hline K30 & LA1491 & PV & R5 & 56 & 3983 & 6702 & 3 & 3 & 18 & 9 & 20 & 11 \\
\hline K30 & LA1491 & PV & $\mathrm{R} 5$ & 51 & 3663 & 7028 & 3 & 3 & 18 & 9 & 21 & 11 \\
\hline K30 & LA1491 & PV & $\mathrm{R} 5$ & 45 & 3100 & 8821 & 3 & 3 & 18 & 8 & 21 & 9 \\
\hline K30 & LA1491 & PV & R5 & 42 & 2287 & 9921 & 3 & 3 & 18 & 9 & 26 & 8 \\
\hline
\end{tabular}


Table 4 continued

\begin{tabular}{|c|c|c|c|c|c|c|c|c|c|c|c|c|}
\hline Building & LA & System & $\begin{array}{l}\text { Tilt } \\
\left({ }^{\circ} \mathrm{C}\right)\end{array}$ & $\begin{array}{l}\text { Lattitude } \\
\left({ }^{\circ}\right)\end{array}$ & $\begin{array}{l}\mathrm{Q}_{\text {cons }} \\
(\mathrm{kWh})\end{array}$ & $\begin{array}{l}\mathrm{Q}_{\text {prod }} \\
(\mathrm{kWh})\end{array}$ & $\begin{array}{l}\text { Optim bat } \\
(\mathrm{kWh})\end{array}$ & $\begin{array}{l}\text { Optim bat no } \\
\text { sell }(\mathrm{kWh})\end{array}$ & $\begin{array}{l}\text { PB optim } \\
\text { (years) }\end{array}$ & $\begin{array}{l}\text { PB optim no } \\
\text { sell (years) }\end{array}$ & $\begin{array}{l}\gamma_{\mathrm{d}} \\
(\%)\end{array}$ & $\begin{array}{l}\gamma_{\mathrm{s}} \\
(\%)\end{array}$ \\
\hline K30 & LA1491 & PV & R5 & 38 & 1864 & 11395 & 3 & 3 & 19 & 9 & 27 & 7 \\
\hline K30 & LA1491 & ORC & R35 & 56 & 3531 & 3351 & 3 & 3 & 26 & 13 & 8 & 8 \\
\hline K30 & LA1491 & ORC & R35 & 51 & 3195 & 3755 & 3 & 3 & 24 & 12 & 10 & 8 \\
\hline K30 & LA1491 & ORC & R35 & 45 & 2581 & 5200 & 3 & 3 & 20 & 10 & 12 & 7 \\
\hline K30 & LA1491 & ORC & R35 & 42 & 1823 & 5932 & 3 & 3 & 19 & 9 & 15 & 7 \\
\hline K30 & LA1491 & ORC & R35 & 38 & 1528 & 7116 & 3 & 3 & 19 & 9 & 17 & 6 \\
\hline K30 & LA1491 & ORC & R5 & 56 & 3531 & 3351 & 3 & 3 & 26 & 13 & 8 & 8 \\
\hline K30 & LA1491 & ORC & R5 & 51 & 3195 & 3755 & 3 & 3 & 24 & 12 & 10 & 8 \\
\hline K30 & LA1491 & ORC & R5 & 45 & 2581 & 5200 & 3 & 3 & 20 & 10 & 12 & 7 \\
\hline K30 & LA1491 & ORC & R5 & 42 & 1823 & 5932 & 3 & 3 & 19 & 9 & 15 & 7 \\
\hline K30 & LA1491 & ORC & R5 & 38 & 1528 & 7116 & 3 & 3 & 19 & 9 & 17 & 6 \\
\hline
\end{tabular}

The logic to order the data is the following: the first five lines corresponds to the five different climates, the next five lines are the same results with another roof tilt, the next ten lines are the same results with another production system, the next twenty lines correspond to another lighting and appliance consumption and finally the second last part of the table are the same results with another building

(a)

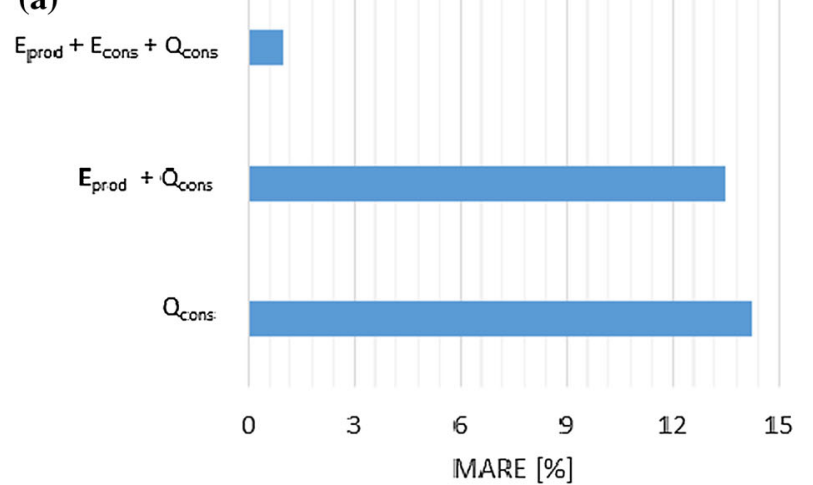

(b)

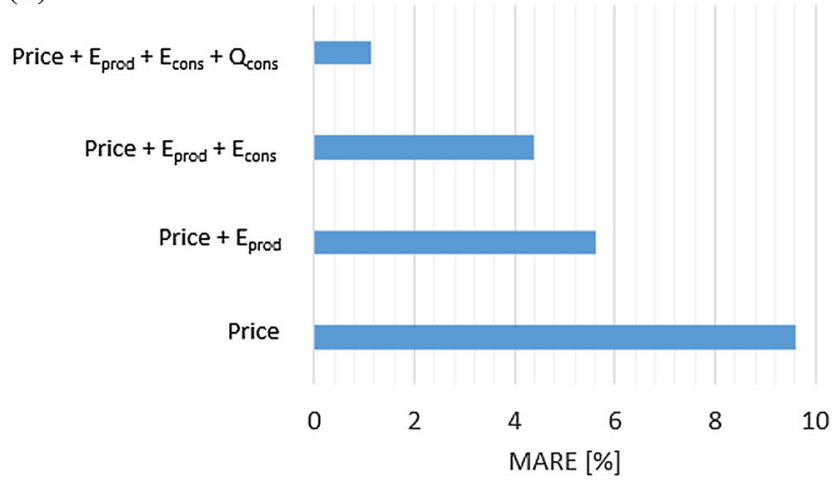

Fig. 7 a MARE to predict the optimal battery size with optimal input. b MARE to predict the optimal payback time size with optimal input

\section{References}

1. REN21: renewables 2015 global status report. http://www.ren21. net/wp-content/uploads/2015/07/REN12-GSR2015_Onlinebook_ low1.pdf (2015)

2. European Commission: Best Practices on Renewable Energy Self-Consumption, p. 339. COM, Brussels (2015)

3. Hoppmann, J., Volland, J., Schmidt, T.S., Hoffmann, V.H.: The economic viability of battery storage for residential solar photovoltaic systems - a review and a simulation model. Renew. Sustain. Energy Rev. 39, 1101-1118 (2014). doi:10.1016/j.rser. 2014.07.068

4. Weniger, J., Tjaden, T., Quaschning, V.: Sizing of residential PV battery systems. Energy Procedia 46, 78-87 (2014). doi:10.1016/ j.egypro.2014.01.160

5. Truong, C., Naumann, M., Karl, R., Müller, M., Jossen, A., Hesse, H.C.: Economics of residential photovoltaic battery systems in Germany: The case of Tesla's Powerwall. Batteries 2(2), 14 (2016). doi:10.3390/batteries2020014

6. Quoilin, S., Konstantinos, K., Mercier, A., Pappone, I., Zucker, A.: Quantifying self-consumption linked to solar home battery systems: statistical analysis and economic assessment. Appl. Energy 182, 58-67 (2016). doi:10.1016/j.apenergy.2016.08.077

7. Quoilin, S., Desideri, A., Wronski, J., Bell, I.: ThermoCycle: a Modelica library for the simulation of thermodynamic systems. In: Proceedings of the 10th International Modelica Conference 2014, Lund, Sweden, 10-12 March 2014

8. Dumont, O., Carmo, C., Randaxhe, F., Quoilin, S., Lemort, V.: Simulation of a passive house coupled with a heat pump/organic Rankine cycle reversible unit. SSB 2014. In: Proceedings of the 9th International Conference on System Simulation in Buildings, Liege, Belgium, 10-12 Dec 2014

9. Castillo-Cagigal, M., Caamano-Martın, E., Matallanas, E., MasaBote, D., Gutierrez, A., Monasterio-Huelin, F., Jimenez-Leube, J.: PV self-consumption optimization with storage and active DSM for the residential sector. Sol. Energy 85, 2338-2348 (2011)

10. Widen, J., Wackelgard, E., Lund, D.: Options for improving the load matching capability of distributed photovoltaics: methodology and application to high latitude data. Sol. Energy 83, 1953-1966 (2009)

11. Dumont, O., Quoilin, S., Lemort, V.: Experimental investigation of a reversible heat pump/organic Rankine cycle unit designed to 
be coupled with a passive house (net zero energy building). Int. J. Refrig. 54, 190-203 (2015)

12. Dumont, O., Quoilin, S., Lemort, V.: Experimental investigation of a scroll unit used as a compressor and as an expander in a reversible Heat Pump/ORC unit. In: 2014 Purdue Conferences: Proceedings of the refrigeration conference in Purdue, Purdue, USA, 14-17 July 2014

13. Dumont, O., Carmo, C., Randaxhe, F., Quoilin, S., Lemort, V.: Performance comparison of two types of technologies associated to a positive energy building: a reversible heat pump/organic Rankine cycle and a heat pump coupled with PV panels. In: SWC 2015: Proceeding of the ISES World Solar Congress, Daegu, Korea, 8-12 Nov 2015

14. Tesla motors. https://www.teslamotors.com/fr_BE/powerwall. Accessed 02 Feb 2016

15. Goldie-Scot: Cost reductions and residential energy storage drivers, Tech. rep., Bloomberg (2016)

16. Masy, G., Georges, E., Verhelst, C., Lemort, V., André, P.: Smart grid energy flexible buildings through the use of heat pumps in the belgian context. Sci Technol Built Environ ASHRAE 21, 800-811 (2015). doi:10.1080/23744731.2015.1035590

17. Georges, E., Gendebien, S., Bertagnolio, S., Lemort, V.: Modeling and simulation of the domestic energy use in Belgium.
In: Proceedings of CLIMA 2013 11th REHVA World Congress \& 8th International Conference on IAQVEC, Praha, Czech Republic, 16-19 June 2013

18. Knight, I., Adnot, J., Alexandre, J.-L., Andre, P., Assimakopoulos, M.-N., Butala, V., Hitchin, R., Masoero, M., Spitzbart, C., Wright, D.: HARMONAC-Harmonizing Air Conditioning Inspection and Audit, procedures in the Tertiary Building Sector, energy Consumption in European Air Conditioning Systems and the Air. https://ec.europa.eu/energy/intelli gent/projects/en/projects/harmonac (2010)

19. EnergyPlus. http://apps1.eere.energy.gov/buildings/energyplus/ weatherdata_about.cfm. Accessed 18 Feb 2015

20. Energinet. http://energinet.dk/DA/El/Solceller/Har-du-solceller/ Sider/Pristillaeg.aspx. Accessed 02 Jan 2015

21. Baetens, R., De Coninck, R., Van Roy, J., Verbruggen, B., Driesen, J., Helsen, L., Saelens, D.: Assessing electrical bottlenecks at feeder level for residential net zero-energy buildings by integrated system simulation. Appl. Energy 96, 74-83 (2012)

22. Weniger, J., Tjaden, T., Quaschning, V.: Sizing of residential PV battery systems. Energy Procedia 46, 78-87 (2012)

23. Quoilin, S., Schrouff, J.: Assessing steady-state, multivariate experimental data using Gaussian processes: the GPExp opensource library. Energies 9(6), 1996 (2016) 